\title{
The Relevance of Vocational High School Programs to Workforce Demands
}

\author{
Yati Siti Mulyati \\ Department of Educational Administration, \\ Faculty of Education, Indonesia University of Education \\ yatiadpend@gmail.com
}

\begin{abstract}
Vocational high schools (VHSs) as one of secondary education types in Indonesia are designed to provide specific technical skills for students either to perform the tasks in work fields or to pursue higher education degree. Many VHS graduates are found unemployed due to the lack of job opportunities and the irrelevance between graduates' skills and the job demands. Their low learning achievements also lead to lack of job opportunities in government agencies as well as business and industrial world (Dunia Usaha Dunia Industri). Thus, VHSs need to maintain their graduates' quality and skill relevance. VHSs' quality is in line with the quality of graduates and their skill relevance. As workforce demands keep increasing following the development of technology, vocational high schools have to improve their performance and their graduates' skill relevancy. Skill relevancy is viewed from lesson planning, implementation, evaluation and benefit so that VHSs can ensure their graduates' skills with the current workforce demands. Industrial practices for students can be a good option for a clear observation in order to see the curriculum relevancy with the workforce demands.
\end{abstract}

Keywords-profile, business/industrial practice, planning, implementation, advantages, evaluation

\section{INTRODUCTION}

Law No. 20 Year 2003 on National Education System Article 3 points out that the national education aims at developing the capability, character, and civilization of the nation for enhancing its intellectual capacity, and is aimed at developing learners' potentials so that they become persons imbued with human values who are faithful and pious to one and only God; who possess morals and noble character; who are healthy, knowledgeable, competent, creative, independent; and as citizens, are democratic and responsible. [1] Education indeed plays a crucial role in the development of a nation as it has something to do with the quality of the human resources.

Indonesia has some educational problems such as the low relevancy of education with workforce demands, the low quality of education, inequality, and ineffectual and inefficient implementation. These problems need to be overcome through formal, non-formal, and informal education. Schools as formal educational institutions should be well integrated with the environment, the social and cultural values, the society and the world of business and industries surrounding them. Hence, their planning, management, implementation, and evaluation should be heavily orientated towards business and industrial dynamic in this changing world.

The increasing demands from many parties related to schools' quality as well as curriculum relevancy force schools' stakeholders to improve their services, following the free flows of trades and workers and the growth of sciences and technologies. High schools, particularly vocational high schools (VHSs) are highly expected to answer these 'calls'. With Link and Match Principle, VHSs should be aware that education comes from the society and for the society. They should realize that one of the types of educational institutions, which are expected to supply the demands of competent employees in Indonesia, is vocational high school.

In line with the process of education equity, schools' quality enhancement efforts are done and focused on the quality improvements of the input, output, process, teachers, facilities, infrastructures and budgeting. The low quality and relevancy of education happens due to several reasons; one of them is the low quality of the teaching and learning process. Additionally, the rigid creates unappealing learning atmosphere. Either students or teachers are not encouraged be too creative and innovative.

Education relevance has something to do with the suitability between what is learned in school with what is needed by the companies/industries.[2] In other words, education relevance is met when the learning materials and the whole curriculum matches the workplace demands. It is all about 'link' and 'match'. In fact, education relevance still becomes a serious problem.

The indicator of education relevance is the appropriateness of the education with the job market demands. It means students should be supplied with relevant knowledge and skills, which are needed later on in their specific work fields.

Education relevance has two types of efficiency strategies - internal and external efficiencies. Internal efficiency strategy is defined as institution's capacity for managing all the existing resources to create qualified output, which is shown from the decreasing number of dropouts and students repeating a grade. External efficiency strategy shows the 
degree of advantages a school contributes to the job market. External efficiency is commonly measured from the quantity of graduates who successfully enter labour market. In other words, external efficiency is related to education relevance and quality.

Education relevance with business and industrial world has currently become Indonesian government concern. Some indicators have been formulated as follows: (1) The local content curriculum should be in line with the condition of school's surroundings; (2) The selection of majors should be matched with students' talents; (3) Majors and sub-majors in vocational high schools should be well-defined; (4) The proportion of VHSs which conduct dual education system and the percentage of students involvement; (5) The percentage of employed and unemployed graduates; and (6) The most enthused type of job by graduates.

\section{RESEARCH METHOD}

This study aimed at describing the relevancy of vocational high school programs to the demands of workforces through a qualitative method. According to [3] "Qualitative research is a particular tradition in a social science than fundamentally depends on watching people in their own territory and interacting with them in language, on their own terms". This notion is suitable with the characteristics of qualitative research proposed by [4] that essentially a naturalistic study tries to observe people in their environment, interact with them, and understand their own language and interpretation (per-spektifemic) about the surrounding world.

The selection process of the research object was based on the objective of the research, which was to evaluate the development program as well as its implementation and also its impact on the quality improvement as well as education relevance in VHSs. These overall efforts are important to give a clear picture of the current conditions to the stakeholders, particularly to the business and industry employers who will hire VHS graduates. Regarding this research objective, the researcher selected some VHSs in Bandung, West Java as the research setting. The reasons are: (1) The credibility of several VHSs in this area is quite high as National Standard Schools $(S S N)$ and International Standard School Stubs (RSBI); (2) The implementation of the industrial units had run and been aided by Directorate of Secondary Vocational Schools Management Republic of Indonesia; (3) Some of the vocational high schools in Bandung had got factory facilities, such as SMK Negeri 3 Jalan Solontongan Bandung, SMK Negeri 1 Jalan Wastukencana Bandung, SMK Negeri 9 Jalan Sukarno Hatta Bandung; and there were some Engineering Education and Training Centers (BLPT) in Bandung which integrated their industrial practices with educational program.

The research instrument was the researcher herself. The researcher should be objective to maintain the validity of the research. According to [5], researcher validity includes the researcher's deep understanding of the field of the study, the researcher's readiness to come into the research setting, academically and logistically. As a human instrument, the researcher served to determine the research focus, to select the respondents, to collect data, to assess data quality, to analyse and interpret the data as well as to draw a conclusion.

In collecting the data, the researcher used three techniques: participant observation, interviews, and documentation. [6] These techniques were continuously and simultaneously conducted to get meaningful and comprehensive data. For the data analysis process, the researcher applied the theory of qualitative data analysis by [7]. This includes: data reduction, data display, data analysis, conclusion drawing, and verification.

\section{FINDINGS AND DISCUSSIONS}

Based on the research findings related to the required data mentioned above, the researcher conducted data analysis and the results are expected to bring new insight for the development of vocational high school programs in the future. Based on the discussion on Management Business Expertise Competency and Travel Business Expertise Competency, it could be seen on Figure 1 as follows.

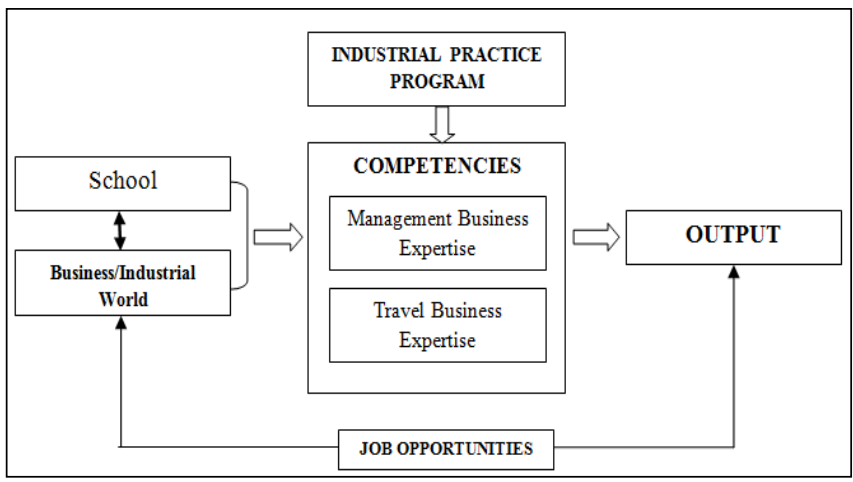

Figure 1. Relevance of Industrial Practice Program with the Work Needs

Vocational high schools (VHSs) in Bandung conducted various programs as an effort to link and match their educational service with the workforce demands. One of these efforts was offering industrial practice program to their students. The results of this study also showed that the two competencies had been successfully gained by VHSs in Bandung (Management Business Expertise Competency and Travel Business Expertise Competency); and these competencies are required during the industrial practice. This program was aimed at optimizing the education relevance of VHSs graduates to the workforce demands through an integrated partnership between the schools and business/industrial agencies.

Every VHS in Bandung maintained good partnerships with business/industrial agencies, which related to the types of majors in these VHSs. The MoU between VHSs and business/industrial companies was also created and this decision was a win-win for both sides. This integration was retained from planning, implementation, until evaluation and monitoring.

The researcher found in the field that the business management competencies were mostly related to trade 
sectors, such as the fulfilment of employees in Yogya Mart, Ramayana, and the other industries. The business travel expertise competencies were focused on service sectors, such as travel agencies and hospitality.

\section{a. The Profile of VHS in Supplying Workforce Demands}

To maintain the quality of SMK Negeri 1 Bandung, the headmaster as well as the whole school's community possessed strong willingness to create competent graduates with high competitiveness in their workforces. This policy referred to: (1) Law No. 20 Year 2003 on National Education System Article 3 and the implementation of Quality Management System ISO 9001: 2008 as well as simultaneous development attempt; (2) Improving school's performance through fulfilling the required quality; (3) enhancing the human resource competencies. SMK Negeri 1 Bandung has set its quality goals as follows: (a) the graduation rate on the national examination every year reached 100\%; (2) the average national examination score was 8,00; and (c) at least $5 \%$ of the total graduates became entrepreneurs (these quality goals were valid in 2010).

The teachers, the administrative staffs, and all the educational personnel also played a great role in the success of the teaching-learning process. Most of the teachers at SMK Negeri 1 Bandung already had relevant bachelor degrees; further training experiences, and apprenticeship certificates from business or industrial agencies. These experiences were fundamental for providing the utmost service for the students.

In 2010, the Research and Development Agency, Curriculum and Books Centre, Ministry of Education and Culture Indonesia established SMK Negeri 3 Bandung as a pioneer in the implementation of Culture and National Character Education as well as Entrepreneurship and Creative Economy, with active learning approach as an effort to create competitive and noble students. Besides, in 2010, Indonesia University of Education in cooperation with Bandung government established SMK Negeri 3 Bandung as a school with Lesson Study success story.

SMK Negeri 11 Bandung, another research subject, also provided the students with qualified human resources. There were 103 competent human resources in this school, including the teachers and the staffs. There were 93 teachers possessing bachelor degrees and 10 teachers owned master degree. These teachers taught subjects which were relevant with their fields of study.

According to the discussion about the results of Management Business Expertise Competence Profile, it could be concluded that SMK Pasundan 1 Bandung, with Drs. Supardi, M.Pd. as the principal, formulated its vision and missions based on the vision of Primary and Secondary Education Foundation (YPDM) Pasundan as follows: "Pengkuh Agamana, Luhung Ilmuna, Jember Budayana" (Religious, Knowledgeable, and Cultured). Meanwhile, the missions were: (1) Preparing and improving the quality of the graduates who can develop sciences, skills and good attitudes as professionals in secondary education level in the field of business and management, who are devoted to God Almighty; (2) Increasing the quality of SMK Pasundan 1 Bandung for national development and educational customers"' satisfaction.

Derived from the discussion of SMK Kencana Bandung's results of Management Business Expertise Competence Profile, with Drs. Bunyamin as the school principal, the vision and missions were stated as follows: "creating an educational institution with excellent characters in terms of achievements and competitiveness, and creating religious, smart, skilful and independent graduates who are able to compete in business/industrial world in national and global level."

Based on the study of SMK Kencana Bandung's results of Management Business Expertise Competence Profile, with Dra. Wamengsih M., M.Pd as the school principal, this school had got its School Statistics Number (NSS) and the National School Identification Number (NPSN) and the department of Business Management was accredited "A".

In SMK Negeri 1 Bandung, the Tour and Travel Business Study Program was accredited 'A'. This school was led by Dra. Komala M.Pd. It was stated in the quality management policy that the principal and all the school community should work hand in hand to produce competent graduates with high competitiveness in job markets or with entrepreneurship skills, which was all referred to the education regulations. The teachers in this school mostly had earned their bachelor degrees, which were relevant with their teaching subject. Besides, they also got additional training from the national government.

In terms of facilities and infrastructure, SMK Negeri 3 Bandung was well equipped with language laboratory, computer laboratory, and tour and travel business laboratory. The teachers were also well educated as they had either bachelor or master degrees in relevant fields. Additionally, this school built a good partnership with Association of The Indonesian Tours and Travel Agencies (ASITA).

Discussing the profile of Tour and Travel Expertise Competencies of SMK Negeri 9 Bandung, it was found that this department was the oldest tour and travel business in Bandung. This school was established as an International Standard School Stub (RSBI). The vision of this school was: "With faith \& devotion, SMK Negeri 9 becomes an excellent school in the field of tourism, which is reliable and appreciated by international society in 2011". The mission was: "Conducting education and training with performance principle”. SMK Negeri 9 International Standard School offered several majors such as: Hospitality, Restaurant, Dressmaking, Makeup, Skin Beauty, Hairstyling, and Pastry.

Derived from the discussion of SMK SMIP YPPT's profile of Tour and Travel Business Study Program, in the last 2009 this school was accredited ' $A$ ' for the following study programs: Hospitality with 86 points and Tour and Travel Business with 87 points. Tour and Travel Business Study Program consisted of three sub-skill programs: (1) Tour and Travel Business; (2) Accommodation Business; and (3) Catering Business. This study program had more than 33 
years of experience and already produced 3247 graduates (31 periods) who had worked in tourism agencies. This school was currently led by Dewi Suharti, S.H.

Based on the discussion of SMK Sandhy Putra's profile of Tour and Travel Business Study Program Expertise Competencies, this school emphasized a vision of developing a tour and travel education with a target of creating noble, knowledgeable, skilful and competent graduates who are ready for works, responsible, and independent. In order to achieve this vision, SMK Sandhy Putra Bandung was determined to produce as many as professional tourism employees in secondary level with job market orientation.

Overall, it could be concluded that vocational high schools' programs in Bandung were mostly relevant to the workforce demands. It was viewed from the following reasons: (1) the arrangement of the programs always involved collaborations with business/industrial agencies; (2) the curriculum development process in vocational high schools involved business/industrial agencies during the planning, implementation, and evaluation; (3) each major in vocation high schools in Bandung maintained partnerships with related business/industrial agencies; (4) the VHSs offered apprenticeship opportunities in the form of industrial practices for the students by engaging business/industrial agencies; and (5) the relevance between VHSs' programs to business/industrial needs could be observed from the average quantity of the employed graduates, which was between 50$70 \%$ of the total graduates.

\section{b. The Planning of Industrial Practices to be Relevant to Workforce Demands}

Essentially, industrial and/or business practices for vocational high school students aim at showing students the real condition in their potential workplaces as well as matching what is actually needed in the workplace with the curriculum content. Thus, the Content Standards $(S I)$ and Graduates Competency Standard $(S K L)$ inside the curriculum need to be adjusted based on the real workforce demands.

Based on the research findings and discussions, the development of the business/industrial practices was synchronized with the School-based Curriculum (KTSP). As the facts in schools from time to time were different from those in the workplaces, VHSs should keep adjusting their curriculum with the current business/industrial needs where the students experienced the apprenticeship programs. The modification should cover not only the basic skills to master but also physical and mental readiness, and appropriate work orientation.

Business/industrial apprenticeships are greatly needed by the students to gain the required expertise competencies in their potential workplaces as such programs are considered learner-centred learning, which focus on competence mastery determined by the business/industrial organizations.

The findings of this study showed that business/industrial practices were conducted in each academic year of the schools through the following stages: (a) visiting a business organization or arranging an industrial tour and matching the expertise competencies with the corporations' demands; (b) verifying apprenticeship candidates; (c) giving training to the students as apprenticeship candidates; (d) equipping the students with letters of assignment; (e) deciding the supervisors; (f) equipping the students with journal book as their 'log book' to write any relevant report; (g) conducting observation and monitoring; (h) conducting evaluation for assessing the students' performances as well as carrying out competency assessment; and (i) giving certificate and souvenirs to the apprentices.

Schools' principal, vice principal of curriculum, vice principal of industry partnership, head of the department, and supervisors were the parties who were involved in the business/industrial practice planning. Meanwhile the corporations played a role as apprenticeship site providers. An MoU was made between the schools and the organizations.

\section{c. The Implementation of Industrial Practices to be Relevant to Workforce Demands}

The implementation of business/industrial practices is actually the realization of Ministry of Education and Culture's regulation, which is executed in schools and in business/industrial organizations. The apprenticeship period was varied, between 3 to 4 months for Business Management department, starting from July until September 2009-2010. On the other hand, the Tour and Travel Business Department was conducted for 6 months, from April until September 2009-2010. It was expected that after this practice, the students could gain new knowledge and skills so that they could easily adapt with their future workforce demands.

Business/industrial practices were mostly supported by schools' stakeholders and community as well as public interests. However, the government itself did not give sufficient encouragement for the success of this program. It would be easier if the government, not the VHSs themselves, took place in bridging the schools and the target companies through socialization. When the government played the role in the intermediary process, partnerships between VHSs and corporations could be easily built.

In terms of business/industrial practice funding, the schools, stakeholders, and the parents through kinship coordination discuss it together. The funding was taken from the schools' budget.

\section{d. The Advantages of Industrial Practices to be Relevant to Workforce Demands}

In fact, industrial practices brought benefits not only for the schools and the students, but also for the business/industrial companies. The advantages of the business/industrial practices for the schools were: (a) the VHSs got opportunities for developing the students' competencies in the work fields; (b) this program was useful for matching the current curriculum with the actual demands in the field, so that the schools could adjust their curriculum; (c) the VHSs were helped in producing competent graduates according to their fields of study; (d) this program enabled 
the VHSs to maintain a good collaboration with business and industrial agencies; and (e) this program was a chance to developing human resource competencies.

The vocational high schools students as the apprentices also got some benefits from business/industrial practices as follows: (a) they obtained wider knowledge and experience from the workplace; (b) they became independent learners; (c) they were trained to be creative, skilful, discipline; confident, and responsible; (d) the students could give recognition; (e) they had the chance to directly evaluate the companies' production process and management.

The advantages of business/industrial practices for the companies/ agencies were: (a) they could get sufficient supply of well-educated employees; (b) they could observe the best apprentices and could possible hire them; (c) the companies could improve their productivity; (d) they got economic advantages; and (e) good partnerships could be built.

Business/ industrial practice programs were maintained and developed as a barometer for evaluating the success of SMK graduates. The evaluation was crucial as the policy for adjusting the curriculum with the current demands of the workplaces.

Derived from the results of this study, the evaluation of business/industrial practice programs was conducted by engaging the school and the companies. It was found that the apprenticeships were run according to the rules from the schools. The supervisors of the companies evaluated the students' performances through the students' journals (reports), which were validated by the tutors (teachers) as well as the companies' supervisor. In short, students' assessment was conducted through their journals, their final reports, and their presentation exams.

Based on the research findings and discussions, it was found that the evaluations of business/industrial practice programs were already done routinely and appropriately. The evaluation results could be accounted for, and the results were satisfying and reasonably objective. This could be proved from the intertwined cooperation between the VHSs and the business/industrial organizations.

During the evaluation process, the schools always did follow-up actions whenever they found some problems encountered by their students during the apprenticeships. It was expected that the problems could be overcome soon, thus it would not affect the achievements of the Business Management as well as Tour and Travel Business Departments.

In general, the collaboration between VHSs and business/industrial agencies were beneficial in terms of giving sufficient experience, knowledge and skills to the students before they graduate. From this direct experience, the students would graduate as competent employees who were ready to be hired. Additionally, the apprenticeship experience also trained the students to be creative, independent, and responsible with their jobs.

\section{CONCLUSIONS AND SUGGESTIONS}

Generally, the material and nonmaterial resources of the vocational high schools in Bandung had played a significant role in achieving the required competencies. In this study, the researcher divided the VHSs into two categories - state VHSs and private VHs.

The implementation of business/industrial practice programs for achieving the required working competencies were done successfully by 11 state and private VHSs in Bandung in order to meet the demands of the workforces. The planning of this program involved multiple stakeholders. Different from the other schools' system, the Business Management expertise competencies at SMK Pasundan 1 Bandung as well as the Tour and Travel Business Expertise Competencies at SMK Negeri 1 Bandung were achieved through workshop. The Tour and Travel Business Expertise Competency program at SMK YPPT was already decided by the school, thus the business agency only needed to follow this decision. In the planning stage of this business/industrial practice program, an MoU was made between the VHSs and the target companies/agencies.

One of the success indicators of this apprentice program was the appropriate plotting of the student apprentices according to their expertise. Besides, the supervision of the students' performance by the teachers as well as the companies' supervisor also strengthened evaluation. In terms of budgeting, the schools also gave significant support for the students from the schools' budget.

The program of business/industrial practices also brought benefits not only for the schools and the students but also for the companies. There were 11 state and private VHSs in this study, which agreed with this notion. The advantages of the business/industrial practices for the schools were: (a) the VHSs got opportunities for developing the students' competencies in the work fields; (b) this program was useful for matching the current curriculum with the actual demands in the field, so that the schools could adjust their curriculum; (c) the VHSs were helped in producing competent graduates according to their fields of study; (d) this program enabled the VHSs to maintain a good collaboration with business and industrial agencies; and (e) this program was a chance to developing human resource competencies. The vocational high schools students as the apprentices also got some benefits from business/industrial practices as follows: (a) they obtained wider knowledge and experience from the workplace; (b) they became independent learners; (c) they were trained to be creative, skilful, discipline; confident, and responsible; (d) the students could give recognition; (e) they had the chance to directly evaluate the companies' production process and management. The advantages of business/industrial practices for the companies/ agencies were: (a) they could get sufficient supply of well-educated employees; (b) they could observe the best apprentices and could possible hire them; (c) the companies could improve their productivity; (d) they got economic advantages; and (e) good partnerships could be built. 
Regarding the evaluation process of the business/industrial practice programs, 11 VHSs, both state and private schools, worked collaboratively with business and industrial world in order to meet the relevant competencies, required in the work fields. Student journals were used as the means of evaluation. The follow-up action of the schools after the evaluation was in the form of curriculum adjustment with the current findings during the business/industrial practice programs. The companies, additionally, also did a follow-up action after the apprenticeship. It was by hiring the ex-apprentices who showed good job performance.

In line with the research problem, objective, findings and discussions, thee researcher propose the following suggestions. Firstly, in formulating vocational high school regulations, Bandung Local Education Authority should consider the following aspects: (a) facilitating VHSs in conducting business/industrial practice programs by bridging the schools with potential companies/agencies; (b) keeping the complete data base of each VHSs for the purpose of research and development, particularly to see the relevance of the VHSs' programs with the workforce demands; (c) assisting VHSs and business/industrial agencies in the implementation of business/industrial practice so that it will be easier for the graduates to be hired in these agencies; (d) assisting VHSs to get ISO, so the business/industrial practice program could be implemented according to the quality management criteria.

Secondly, the vocational high schools which conduct business/industrial practice programs should do the following things: (a) maintaining the good partnerships with potential business and industrial agencies by creating the MoU between these parties; (b) planning the program by involving not only the schools' stakeholders but also the representatives of the agencies; (c) conducting internal audit within the schools, covering the business/industrial practice curriculum as well as the implementation of business/industrial practice program itself, thus the report will be transparent and accountable; (d) giving the students wider opportunities to reach the companies outside Bandung area; (e) optimizing the budget sources for business/industrial practices not only from the internal sources but also from external parties, such as from relevant companies.

Lastly, the business/industrial agencies as the most important party in this program should do the following things: (a) these agencies should build awareness to help VHSs reach their goals to create competent graduates, because companies essentially will also get many benefits from this program; (b) each company/agency should have a specific structure of collaboration with VHSs. This structure is crucial, as the implementation of the apprenticeship program will have a clear focus. Usually HRD (Human Resources Development) would take care of this matter: and (c) optimizes the Corporate Social Responsibility (CSR) financial support for the development of the VHSs.

\section{REFERENCES}

[1] Law of Republic of Indonesia No. 20 Year 2003 on National Education System.

[2] Ibrahim, R. \& Sukmadinata, N.S. 2009. Perencanaan Pengajaran.Jakarta: Rineka Cipta.

[3] Kirk, J. \& Marc L. M. 1986. Reliability and Validity in Qualitative Research. London: Sage Publications, Inc.

[4] Nasution. 1992. Metode Penelitian Naturalistik Kualitatif. Bandung: Tarsito.

[5] Sugiyono. 2007. Metode Penelitian Kuantitatif, Kualitatif, $R \& D$. Bandung: Alfabeta.

[6] Moleong, L. J. 1994. Metodologi Penelitian Kualitatif. Edisi Revisi. Bandung: Remaja Rosdakarya.

[7] Miles, M. B. \& Huberman A. M. 1992. Analisis Data Kualitatif (Translated by Tjetjep Rohendi Rohidi). Jakarta: UI Press. 